\title{
Establishment and Characterization of Eye Muscle Cell Line from Snow Trout, Schizothorax richardsonii (Gray, 1832), a Vulnerable Coldwater Fish, for In Vitro Studies
}

\author{
Murali Sanjeev Kumar ${ }^{1}$, Pankaj Soni ${ }^{1}$, Neha Singh ${ }^{1}$, Ravindra Kumar ${ }^{1}$, Shreya \\ Srivastava ${ }^{1}$, Akhilesh Kumar Mishra ${ }^{1}$, Vijay Kumar Singh ${ }^{1}$, Basdeo Kushwaha ${ }^{1, *}$ (i)
}

\begin{abstract}
${ }^{1}$ Molecular Biology and Biotechnology Division ICAR-National Bureau of Fish Genetic Resources, Canal ring Road, P.O. Dilkusha, Lucknow-226002, Uttar Pradesh, India.
\end{abstract}

\section{Article History}

Received 04 June 2020

Accepted 09 December 2020

First Online 10 December 2020

\section{Corresponding Author \\ Tel.: +919450912730 \\ E-mail: basdeo.scientist@gmail.com}

\section{Keywords}

Cell line

Cytotoxicity

India

Mercury chloride

NRFC

Schizothorax richardsonii

\begin{abstract}
Schizothorax richardsonii, commonly called snow trout is a vulnerable coldwater fish distributed in India and adjoining countries, is an important resource as food, ornamental and game fishery. A cell line, designated as SREM-1, has been established from the eye muscle of $S$. richardsonii using explant method and cultured in Leibovitz's L-15 medium. The growth studies at $20-32^{\circ} \mathrm{C}$ temperatures and $5-20 \%$ of fetal bovine serum (FBS) concentrations revealed that SREM-1 cells exhibited optimal growth at $28^{\circ} \mathrm{C}$ in L-15 medium containing $20 \%$ FBS. Cell type was confirmed primarily as epithelial in nature by immuno-phenotyping assay and was sub-cultured for $>55$ times since its development. The origin of the cell line was confirmed by sequencing of cytochrome oxidase c subunit I and 16S rRNA genes. SREM-1 cell line is free from mycoplasma contamination and has been cryopreserved at different passage levels with revival efficiency of $70-80 \%$ after 6 months. The SREM- 1 cell line was successfully transfected and also employed for evaluating in vitro cytotoxicity against a heavy metal, mercuric chloride. The newly established cell line of this vulnerable species would be useful as a model for aquatic toxicological and transfection studies.
\end{abstract}

\section{Introduction}

The common snow trout, Schizothorax richardsonii (Gray, 1832) belonging to Cyprinidae family, is an important coldwater fish species inhabiting high altitude hill streams of India and neighbouring countries like Afghanistan, Nepal and Pakistan. It is a much-sought after species for its delicacy in Indian upland areas. It has been studied as a potential model species for investigating thermal stress (Kapila et al., 2002; Barat et al., 2016). The fishery of this important species has declined, due to habitat destruction and over exploitation, and has been designated as a vulnerable species in the International Union for Conservation of Nature (IUCN) red list (Vishwanath, 2010). Availability of a cell line could stimulate further research which can lead to a better understanding of biological and molecular processes of this coldwater species. The availability of a cell line could also be used in future, once the cloning and somatic cell nuclear transfer technologies develop for fishes.

Fish cell lines are presently considered as an ethical solution for sacrificing fish specimens for research purposes and also easy to work for supporting biomedical applications, useful for isolating virus and immunological studies, provide the best source of chromosome preparation for banding/ staining purposes etc. (Hightower and Renfro, 1988; Driever and Rangini, 1993; Villena, 2003; Nagpure et al., 2016). The past few years have seen plenty of activities in applications of cell lines in fisheries specially for diseases, pharmacology and toxicology along with the opening of new and exciting research avenues.

Globally, few cell lines have been developed from important cold water fish species, like the Salmo gairdneri, S. salar, Oncorhynchus keta, O. kisutch, 0. 
mykiss, O. nerka etc. (Wolf and Quimby, 1962; Lannan et al., 1984; Bols et al., 1994; Rodriguez et al., 2014). However, some fish cell lines were also developed in India, like Puntius chelynoides and Tor putitora (Lakra et al., 2006; Goswami et al., 2012), but still, there is a paucity of cell lines from the fishes of cold water ecosystems that needs to be developed for research and development (R\&D) purposes. A fin cell line from $S$. richardsonii was developed by Goswami et al. (2013), which is no longer available in the National Repository of Fish Cell Lines (NRFC) due to technical problems. The present study describes the development and characterization of an eye muscle cell line from $S$. richardsonii as a material for germplasm conservation and its wide applications in toxicity testing as well as pathological and transfection studies.

\section{Materials and Methods}

\section{Generation of Primary Culture and Routine Maintenance}

Healthy live specimens of $S$. richardsonii $(n=10$ with 10-20 g weight) were collected from Kalsa stream, Chafi, Uttarakhand, India, and transported to the laboratory. Specimens were acclimatized for a week in water having $15^{\circ} \mathrm{C}$ temperature with proper aeration and feed, where one-third of the water was changed every alternate day. Fish specimens were handled following the strict guidelines issued by Control and Supervision of Experiments on Animals (CSEPA), Government of India and the experimental protocols were approved by Institutional Animal Ethics Committee (AEC) of ICARNational Bureau of Fish Genetic Resources, Lucknow as per the guidelines of (CSEPA) Government of India.

Explant method was followed for the development of primary culture. Before setting explants, the specimens were kept overnight in aerated freshwater tank added with $1 \mathrm{ml}$ of antibiotic-antimycotic solution (CELLclone, Genetix Brand) per $100 \mathrm{ml}$ of water to minimise bacterial or fungal contamination. The specimens were then anaesthetized on ice and wiped with $70 \%$ ethanol before dissection. Eye muscle tissues were then aseptically removed using a sterile scalpel blade, minced into small pieces, washed repeatedly with $1 \mathrm{ml}$ of phosphate buffer saline (PBS, HiMedia, India), containing $10 \mathrm{X}$ antibiotics-antimycotics mixture. The tissue fragments were then explanted into a $25 \mathrm{~cm}^{2}$ cell culture flask (ThermoFisher Scientific, USA) added with $200 \mu \mathrm{l}$ of fetal bovine serum (FBS, ThermoFisher Scientific, USA) and then the flask kept in a vertical position for $2 \mathrm{~h}$ to allow the culture to attach to the surface of the flask. Later, $5 \mathrm{ml}$ of Leibovitz's L-15 medium (HiMedia, India) supplemented with 20\% FBS and $100 \mu \mathrm{l}$ of antibiotic and antimycotic solution were added to the flask and incubated at $28^{\circ} \mathrm{C}$ in an incubator, where half the medium was changed every 3 or 4 days. Upon reaching $80-90 \%$ confluency, the cells were subcultured at 1:2 ratio following standard trypsinization method by trypsin-EDTA solution (trypsin $0.25 \%$, EDTA $0.02 \%$ in PBS) (HiMedia, India). No antibiotics were used thereafter and the passage number was recorded every time after splitting the flask.

\section{Cryopreservation}

The cells were cryopreserved at various passage levels for future use. Cells were trypsinized in the flask at $70-80 \%$ confluency level, harvested and collected in a $15 \mathrm{ml}$ centrifuge tube by centrifugation at $1,500 \mathrm{rpm}$ for $5 \mathrm{~min}$. The cells were then washed once with $2 \mathrm{ml}$ PBS and re-suspended in freezing medium (containing pre-cooled L-15 medium supplemented with 20\% FBS and $10 \%$ dimethyl sulphoxide) at a density of $1 \times 10^{6}$ cells $/ \mathrm{ml}$. The cells were then transferred to $1.8 \mathrm{ml}$ cryovials and stored at $-20^{\circ} \mathrm{C}$. After $4 \mathrm{~h}$, the cells were kept overnight at $-80^{\circ} \mathrm{C}$ and then transferred to liquid nitrogen (LN2) vapour phase for cryopreservation. After 6 months, the cells were revived and checked for cell viability. The cryopreserved cells were thawed quickly at $37^{\circ} \mathrm{C}$ in a water bath and mixed drop-wise with complete L-15 medium in a $15 \mathrm{ml}$ centrifuge tube. The cells were then centrifuged at $1500 \mathrm{rpm}$ for $5 \mathrm{~min}$ and the pellet was re-suspended in $5 \mathrm{ml}$ complete medium. Cell viability was checked with a haemocytometer following trypan blue staining. The revived cells were seeded into $25 \mathrm{~cm}^{2}$ flask and incubated at $28^{\circ} \mathrm{C}$ for further culture.

\section{Growth Studies}

To determine the optimum temperature and serum concentration, the eye muscle cells were grown at different temperature and FBS concentrations. The effect of incubation temperature was determined by seeding cells at passage number 40 at a density of $1 \times 10^{5}$ cells in different $25 \mathrm{~cm}^{2}$ tissue culture flasks. After cell attachment, the tissue culture flasks were incubated at $20,24,28$ and $32^{\circ} \mathrm{C}$ temperatures for growth studies. The experiment was conducted in triplicates and cell densities measured using a haemocytometer for five consecutive days. Effect of serum was determined by seeding cells at passage 46 at a density of $1 \times 10^{5}$ cells in different $25 \mathrm{~cm}^{2}$ tissue culture flasks with 5, 10, 15 and 20\% FBS concentrations incubated for five successive days at the optimum temperature obtained from above experiment.

\section{Plating Efficiency and Doubling Time}

Cell line at 42 passage was also used to determine the plating efficiency (in terms of cells' attachability and growth). 100, 500 and 1000 cells were seeded in $25 \mathrm{~cm}^{2}$ tissue culture flasks in triplicates. The cells were incubated at $28^{\circ} \mathrm{C}$ in L-15 medium with $20 \%$ FBS, where $1 / 3^{\text {rd }}$ of the culture medium was changed every $4^{\text {th }}$ day. After 10 days of incubation, the culture medium was discarded and cells were washed with PBS and fixed 
using methanol and stained with crystal violet. The individual cell colonies in a flask were then counted under the inverted microscope (Nikon Eclipse TS100, Japan) to know the plating efficiency (Freshney, 2005). The calculation of population-doubling time of the cell line was performed at two different passages, viz. 30 and 45, where cells were counted using a haemocytometer under an inverted microscope (Freshney, 1994).

\section{Cell Line Characterization}

\section{i) Mitochondrial Genes Sequencing}

To authenticate the origin of the cell line, $\mathrm{COI}$ and $16 \mathrm{~S}$ rRNA genes were sequenced on $A B I 3500$ DNA analyzer (Applied Biosystems, USA) using DNA isolated from SREM-1 cells harvested at 35 passage level. Universal primers for COI [FishF1 5'-TCAACCAACCACAA AGACATTGGCAC-3'; FishR1 5'- TAGACTTCTGGGT GGCCAAAGAATCA3' (Ward et al. 2005)] and 16S rRNA [F 5'- CGCCTGTTTATCAAAAACAT-3'; R 5'-CCGGTCTGAAC TCAGATCACGT-3' (Palumbi et al. 1991)] genes were used. The resulting DNA sequences for both the genes were blasted and aligned with respective sequences of $S$. richardsonii available at National Centre for Biotechnology Information (NCBI) databases.

\section{ii) Chromosome Analysis}

Cells at 47 and 59 passage levels were sub-cultured in a T-75 culture flask, where the cells were trypsinized and processed for chromosome analysis. Next day fresh $8 \mathrm{ml} \mathrm{L}-15$ media along with $25 \mu \mathrm{l}$ of $0.05 \%$ colchicine was added in the flask, which was then incubated at $28^{\circ} \mathrm{C}$ for $2 \mathrm{~h}$. Cells were then harvested and collected in a $15 \mathrm{ml}$ tube and incubated with $5 \mathrm{ml}$ hypotonic solution at $28^{\circ} \mathrm{C}$ for $25 \mathrm{~min}$ and after this $1 \mathrm{ml}$ chilled Carnoy's fixative was added and cells were pelleted after centrifugation. Later, the cells were re-suspended in fresh $5 \mathrm{ml}$ fixative and kept for $2 \mathrm{~h}$ at $4^{\circ} \mathrm{C}$ for fixation of the cells. The same fixation step was repeated for 4-5 times. Slides were then prepared using the conventional drop-splash technique (Freshney, 2005). Diploid chromosome number in 100 metaphase spreads was counted under a light microscope (Leica DM LB2, Germany).

\section{iii) Immuno-Phenotyping}

Morphological confirmation of the cells was done by immune-phenotyping. The cells at 35 passage level were grown at $28^{\circ} \mathrm{C}$ for $24 \mathrm{~h}$ on coverslips placed on 30 $\mathrm{cm}$ petri plate. The cells were then washed with $\mathrm{PBS}$ and fixed in methanol-acetone solution $(1: 1)$ at $-20^{\circ} \mathrm{C}$ for $20 \mathrm{~min}$. The solution was then discarded and blocking of unspecific sites was done with $3 \%$ Bovine Serum Albumin (BSA) dissolved in PBS for $1 \mathrm{hr}$ at $37^{\circ} \mathrm{C}$. The cells were then stained with primary antibodies, viz. mouse anti-cytokeratin (pan) and mouse anti-fibronectin antibodies (Sigma-Aldrich, USA) at 1:100 dilutions and incubated overnight at $4^{\circ} \mathrm{C}$. For control group, $1 \%$ BSA in PBS was used in place of primary antibodies. Next day, the cells were washed with PBS and incubated with secondary antibody, viz. fluorescein thiocyanate (FITC)labeled rabbit anti-mouse IgG (Sigma-Aldrich, USA) diluted 1:100 times in PBS, for $1 \mathrm{hr}$ at $37^{\circ} \mathrm{C}$. After a final wash with PBS, the coverslip was mounted in buffered glycerol and monitored under a fluorescent microscope (Nikon Eclipse TS100, Japan.

\section{iv) Transfection}

The cells at 37 passage levels were cultured in a 6 well plate in duplicates. After $24 \mathrm{~h}$, sub-confluent monolayers were transfected with $1.5 \mu \mathrm{g}$ of pAcGFP1N1 eukaryotic expression vector (Takara Clontech, USA) using lipofectamine 2000 reagent (Invitrogen Corporation, Grand Island, NY, USA). After $48 \mathrm{~h}$, the transfected cells were checked under a fluorescent microscope for the green fluorescent signals.

\section{v) Mycoplasma Detection}

PCR based method was used for mycoplasma detection in the cell line. Cells at 37 passage level were allowed to grow in complete medium (L-15+20\% FBS) without antibiotics for 5 days. Then, $2 \mathrm{ml}$ of the supernatant from the flask was transferred to microcentrifuge tube and the tube centrifuged at 13000 rpm for $30 \mathrm{~min}$. The pellet formed was dissolved in $50 \mu \mathrm{l}$ of $1 \times$ TE buffer, vortexed and heated at $95^{\circ} \mathrm{C}$ for $10 \mathrm{~min}$. The EZdetectTM PCR Kit (HiMedia, India), which is based on the amplification of the spacer region between $16 \mathrm{~S}$ and 235 ribosomal RNA (rRNA) genic sequence, was used for this. PCR was carried out using the reagents and cycling conditions as per the manufacturers' instructions. The amplified products were separated in $2 \%$ agarose gel and visualized under UV transilluminator (UVP, USA).

\section{vi) Cytotoxicity Testing}

Cytotoxicity studies were carried out using alamarBlue and Neutral Red assays for an important heavy metal, viz. mercury chloride as the standard protocol provided by the manufacturer.

\section{a) alamarBlue Assay}

Briefly, about 50,000 cells were seeded per well, in triplicates, in 96 well plate along with the control and the plate was incubated at $28^{\circ} \mathrm{C}$. After $24 \mathrm{~h}$, the culture medium was removed and $100 \mu \mathrm{l}$ each of 11 concentrations of analytical grade $\mathrm{HgCl}_{2}$ (Sigma-Aldrich, USA), viz. 5000, 4500, 4000, 3500, 3000, 2500, 2000, $1500,1000,500$ and $100 \mu \mathrm{M}$, prepared in complete culture medium, was poured in each well and kept the plate for $24 \mathrm{~h}$ exposure at $28^{\circ} \mathrm{C}$. After $24 \mathrm{~h}$ of exposure, 
$10 \mu \mathrm{l}$ alamarBlue reagent was added to each well and incubated for $2 \mathrm{~h}$. Then absorption readings at 570 and $600 \mathrm{~nm}$ wavelengths were recorded using a spectrophotometer. Inhibition constant $\left(\mathrm{IC}_{50}\right)$ value was then calculated using GraphPad Prism 6 software.

\section{b) Neutral Red (NR) Assay}

For NR assay, the SREM-1 cells were seeded, in triplicates, in 96 well plates at a density of $1 \times 10^{5}$ cells/ well along with control and the plate was incubated at $28^{\circ} \mathrm{C}$ for cell attachment. After cell attachment, $100 \mu \mathrm{l}$ each in 6 concentrations of analytical grade $\mathrm{HgCl}_{2}$ (Sigma-Aldrich, USA), viz. 375, 187.5, 93.75, 46.875, 23.43 and $11.71 \mu \mathrm{M}$, prepared in culture medium, were added in each well and incubated at $28^{\circ} \mathrm{C}$ for $24 \mathrm{~h}$ for exposure. After $24 \mathrm{~h}$, the medium was discarded and wells were washed with PBS followed by addition of 100 $\mu \mathrm{L} N R$ working solution and incubation at $28^{\circ} \mathrm{C}$. After $3 \mathrm{~h}$ of incubation, the NR medium was decanted, the wells washed with PBS and $150 \mu \mathrm{L}$ of NR de-staining solution was added. Then, absorption readings at 540 wavelengths were recorded using spectrophotometer and the $\mathrm{IC}_{50}$ value was calculated using GraphPad Prism 6 software.

\section{Results}

\section{Primary Culture}

Primary cell cultures were initiated from eye muscle tissue of $S$. richardsonii using explant culture method. The cells migrated from the tissue fragments on $3^{\text {rd }}$ day and formed monolayer within 18 days that could be sub-cultured at an interval of 4-5 days. Initial cultures consisted of heterogeneous cell population but later passages exhibited epithelial-like cell types. The cells were split at 1:2 ratio and this cell line were subcultured for $>55$ times since its initiation and has been named as S. richardsonii Eye Muscle (SREM-1) cell line (Figure 1).

\section{Cryopreservation}

SREM-1 cells were cryopreserved at various passage levels and were successfully revived after 6 months with $78 \pm 3 \%$ viability. The revived cells formed a monolayer within 5 days at $28^{\circ} \mathrm{C}$. The cells retained their normal growth, doubling time and attachment ability without showing any morphological changes.
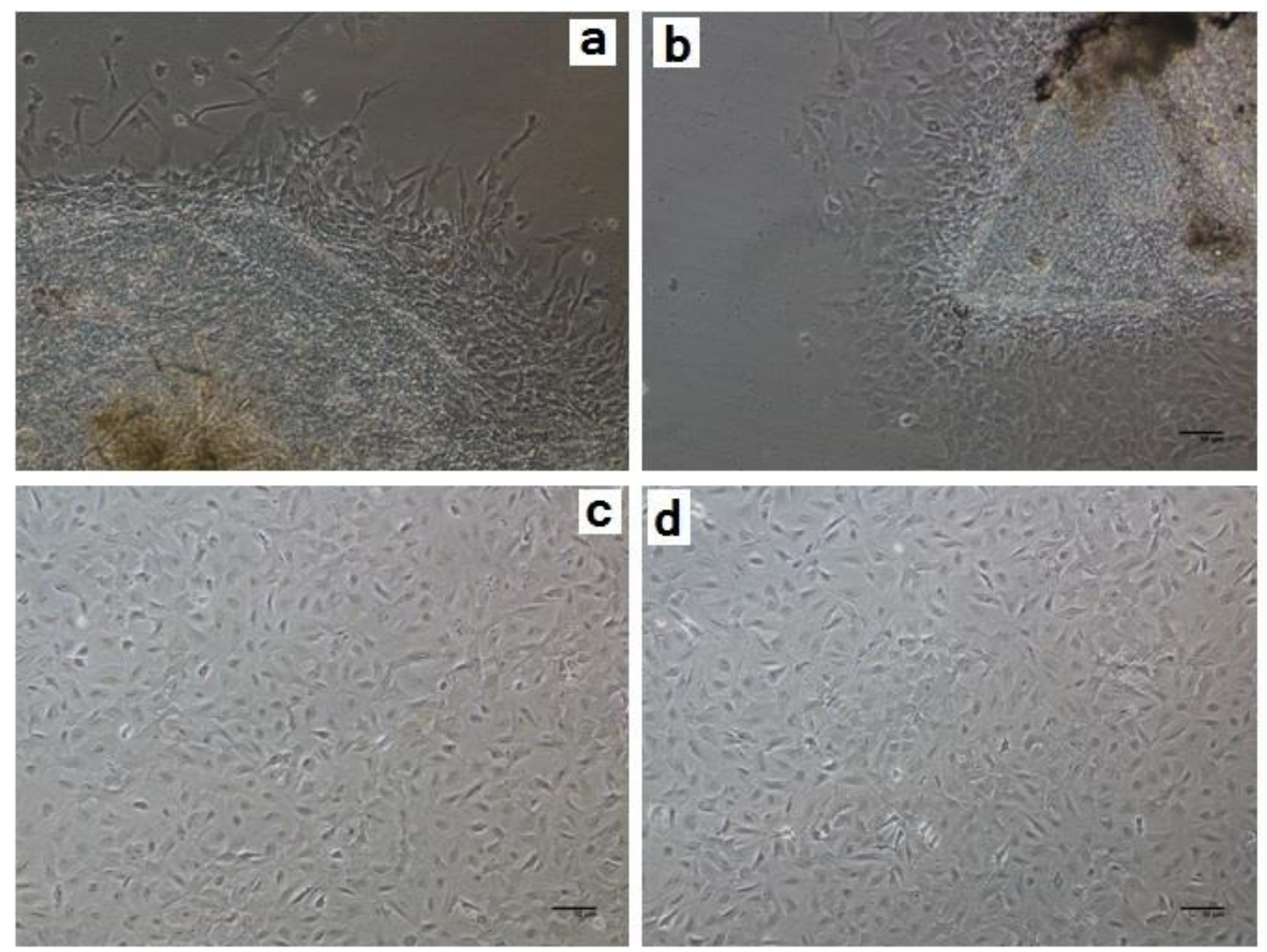

Figure 1. Photographs depicting stages of SREM-1 cell line: (a) eye muscle explant showing radiation on day 4, (b) eye muscle explant on day 19, (c) monolayer of cells at 35 passage level, and (d) monolayer of cells at 50 passage level 


\section{Effect of Temperature and FBS on Growth and Plating Efficiency}

SREM-1 cells could be grown at varying temperatures ranging from 20 to $32^{\circ} \mathrm{C}$, but maximum growth was observed at $28^{\circ} \mathrm{C}$ (Figure 2a). Similarly, SREM-1 cells could grow at different FBS concentration ranging from 5 to $20 \%$. There was an increase in growth rate with increase in FBS concentration, in which maximum growth was seen at $20 \%$ and least growth seen at $5 \%$ (Figure 2 b). SREM-1 cells seeded at the densities of 100,500 and 1000 cells per flask exhibited $6.3,10.6$ and $15.23 \%$ plating efficiency, respectively. The doubling time was estimated to be $34 \mathrm{~h}$.
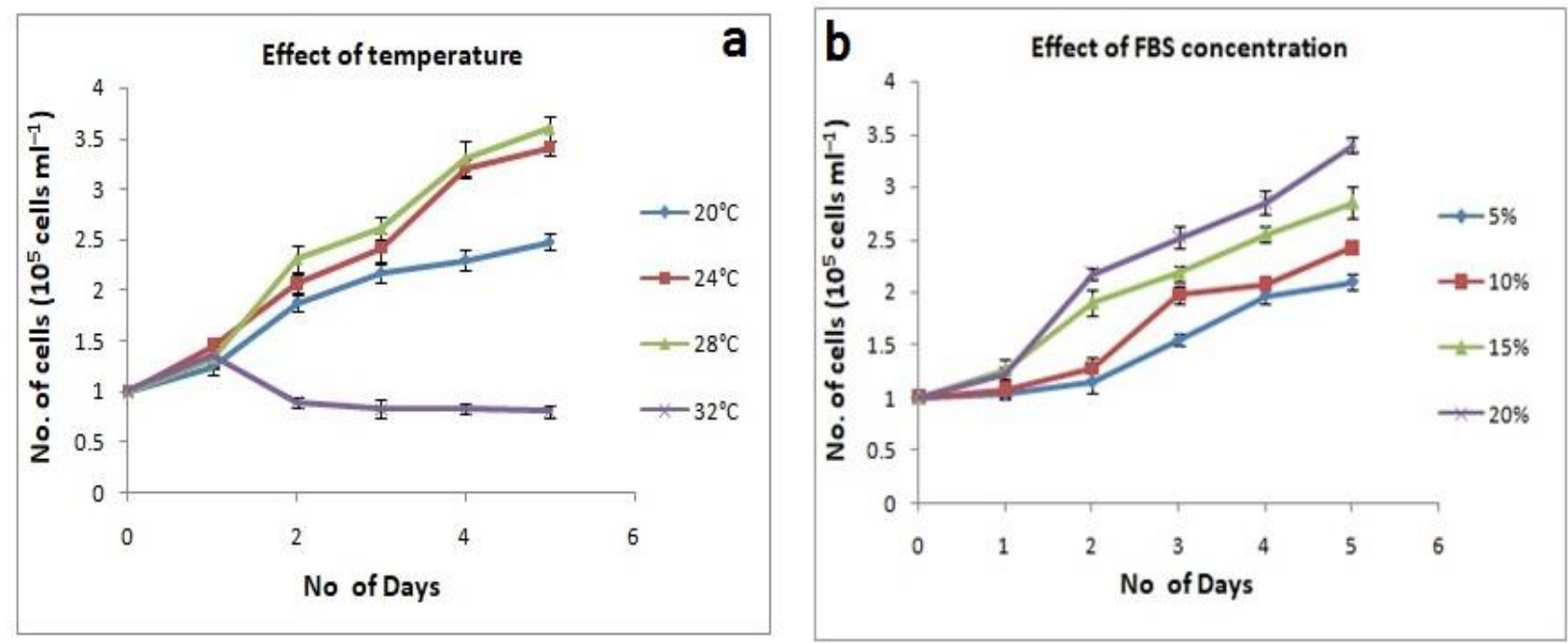

Figure 2. Graphs showing the effect of: (a) temperature, and (b) serum on SREM-1 cells.

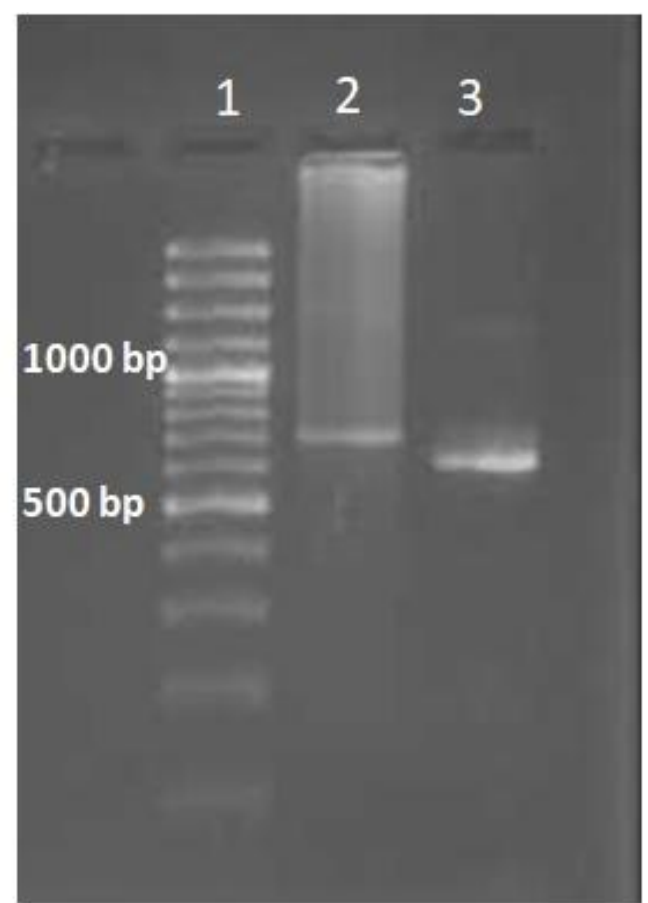

Figure 3. Gel image of PCR product: Lane 1: 100 bp DNA marker, Lane 2: COI gene amplicon, Lane 3: 16S rRNA gene amplicon 


\section{Immuno-Phenotyping and Mycoplasma Detection}

Immuno-staining results showed a strong positive signal in the cells incubated with cytokeratin, but not in fibronectin, which confirmed that SREM-1 cells are epithelial-like (Figure 5). It was confirmed from the amplification that the cell line is free from any mycoplasma contamination, as there was no amplification of mycoplasma specific DNA content in the cell growth medium of SREM-1 cells at 40 passage level (Figure 6).

\section{Cell Transfection}

The transfection of SREM-1cells with green fluorescent protein (GFP) plasmid pAcGFP1-N1

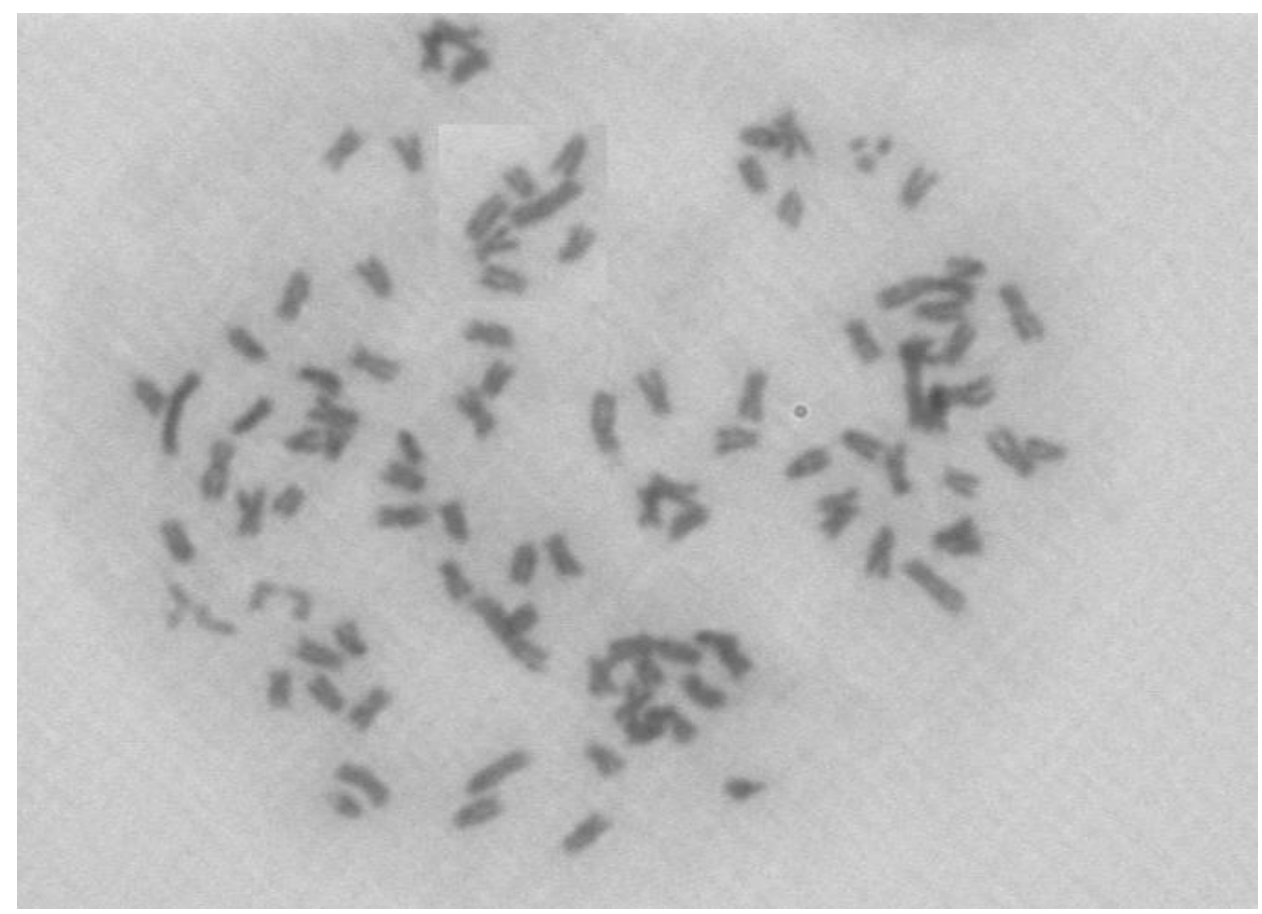

Figure 4. Metaphase chromosome spread in SREM-1 cell line.

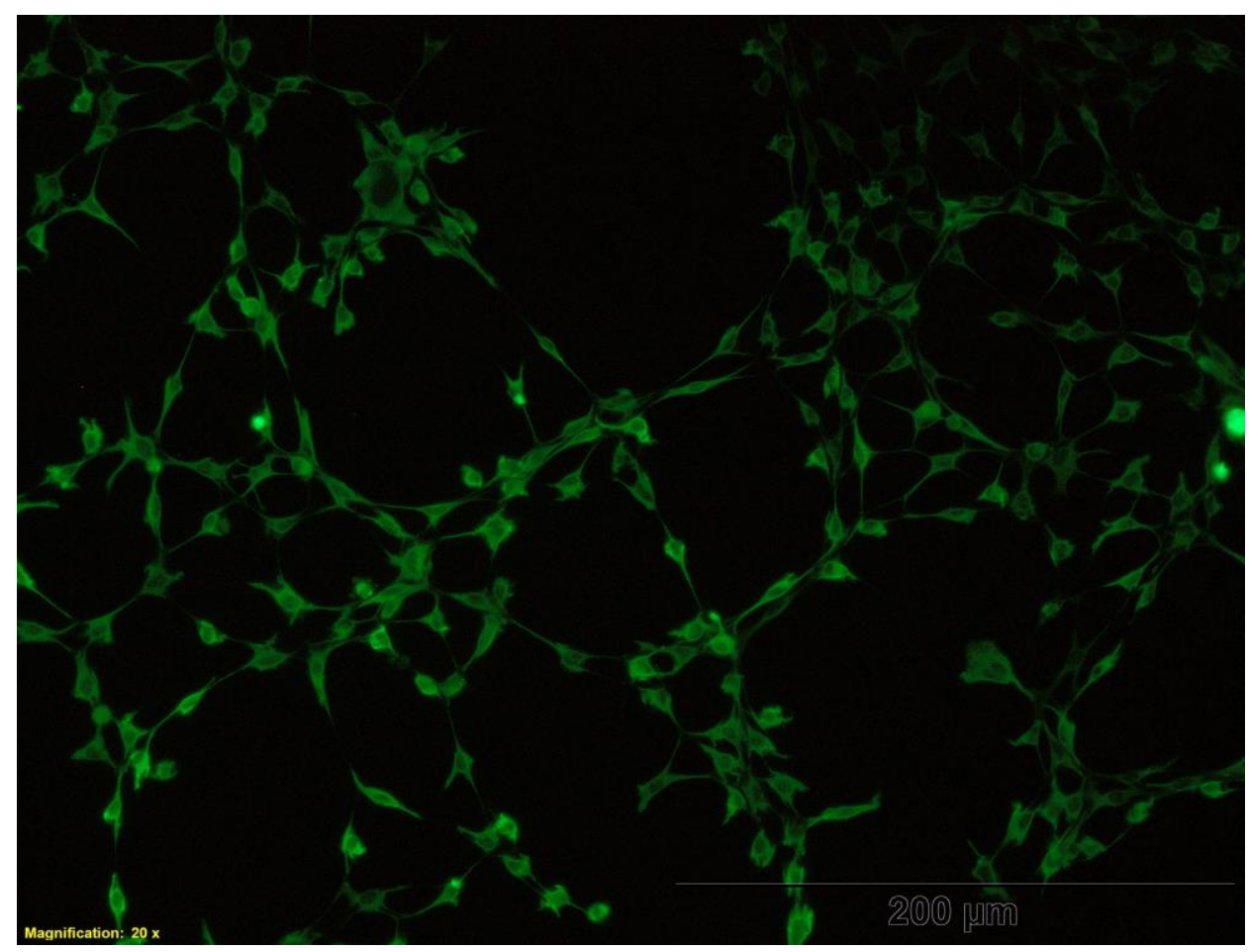

Figure 5. SREM-1 cells showing positive to cytokeratin marker 
exhibited fluorescent signals at $48 \mathrm{~h}$ post-transfection, with $5 \pm 1.2 \%$ transfection efficiency thus, indicating the suitability of these cells for transfection and gene expression studies (Figure 7).

\section{Cytotoxicity Tests}

Cytotoxicity induced due to heavy metal, mercury chloride, was noticed in SREM-1 cells at $24 \mathrm{~h}$ after exposure. Cells in control wells had a regular shape, whereas treated cells lost their regular shape and size. Change in cell morphology, such as cell shrinking, rounding and floating of dead cells, was observed at higher doses. The cytotoxic effects on morphology were found to be concentration dependent. A decrease in absorption values was noticed with increasing concentration of $\mathrm{HgCl}_{2}$. At the highest dose, all cells appeared to be dead. $\mathrm{IC}_{50}$ values for $\mathrm{HgCl}_{2}$ were determined to be $411.0 \pm 2.5$ and $321.9 \pm 1.77 \mu \mathrm{M}$ using alamarBlue and NR assays, respectively (Figure 8a, b).

\section{Discussion}

Schirmer (2006) proposed to improve and utilize cell lines as an alternative for regulatory testing of chemicals and effluents using fish. Fish cell lines have

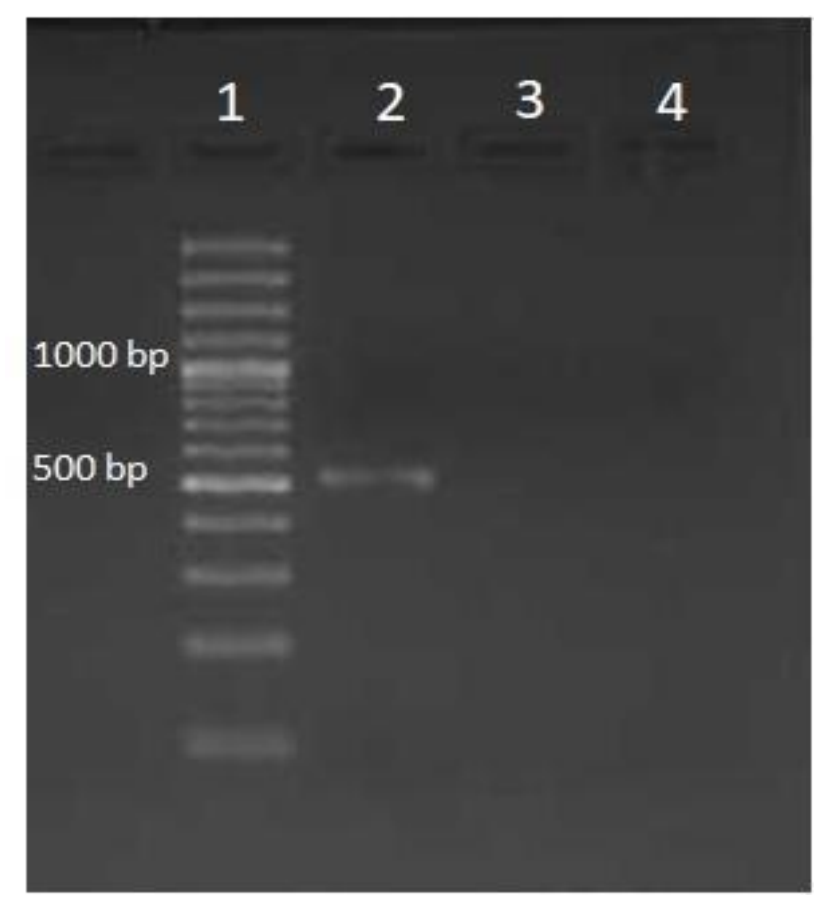

Figure 6. Gel image of PCR products used for mycoplasma testing: Lane 1: 100 bp DNA ladder, Lane 2: positive control, Lane 3: negative control, and Lane 4: SREM-1 cell supernatant.

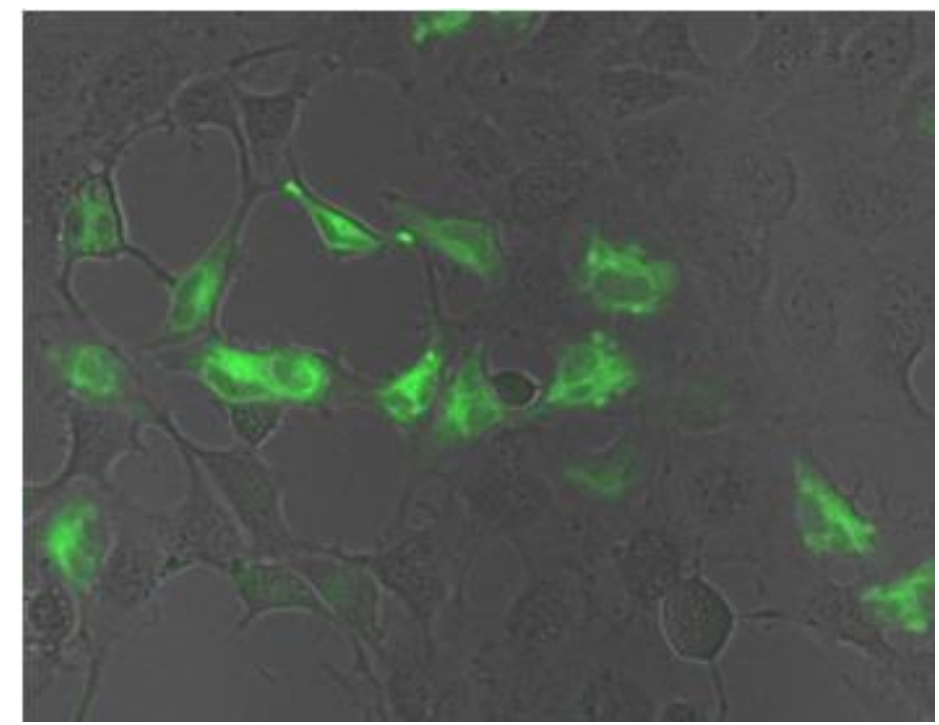

Figure 7. Fluorescence image showing the expression of GFP gene in SREM-1 cell line transfected with pAcGFP1-N1 plasmid. 
become an important resource in recent years with numerous applications in virology, aquatic toxicology, immunology, endocrinology, developmental biology, drug discovery etc. (Castano et al., 2003; Huang and Han, 2014; Nagpure et al., 2016; Soni et al., 2018). This is evident from the availability of fish cell lines in various cell line repositories viz. 70 fish cell lines accessions in National Repository of Fish Cell Lines (NRFC) (http://mail.nbfgr.res.in/nrfc/celline-available.php),

ICAR- National Bureau of Fish Genetic Resources (NBFGR), Lucknow, India,) 25 in European Collection of Authenticated Animal Cell Cultures (https://www.pheculturecollections.org.uk/products/celllines/generalcell /search.jsp?searchtext=fish\&dosearch=true), 8 in American Type Culture Collection (https://www.atcc.org/en/Products/Cells_and_Microor ganisms/Cell_Lines/Animal/Fish.aspx) etc. Cellosaurus-a knowledge resource on cell line lists 714 fish cell lines (https://web.expasy.org/cgi-bin/cellosaurus/search).

The snow trout, S. richardsonii, has an enormous aquaculture potential, but at the same time, it is susceptible to various pathogens (Mallik et al., 2010; Tandel et al., 2020), aquatic pollution etc (Khan, 2004). In the present study, a new cell line, named SREM-1, was established from eye muscle tissue of $S$. richardsonii and characterized using various markers to support its potential applications in toxicology, virology and gene expression studies in coldwater fishes. The cell line also serves as an in vitro model of this important vulnerable coldwater fish species. The SREM-1 cell line has been deposited in NRFC at ICAR-NBFGR, Lucknow, India, with accession code NRFC060 for further storage and distribution to researchers for R\&D works.

Eye cell lines have been developed from a few fish species, like rohu and zebrafish (Ahmed et al., 2009; Babu et al., 2011; Nambi et al., 2015). The SREM-1 cell line was maintained in L-15 medium with $20 \%$ FBS without need for any growth factors. The L-15 culture medium has been used in a number of other fish cell lines as being the preferred media (Lakra et al., 2011; Chen et al., 2019). Similar serum concentrations were used in other fish cell lines (Rodriguez et al., 2014; Singh et al., 2019; Chen et al., 2019). It was demonstrated in the present study that even though the SREM-1 cells could be cultured at wide temperature range of $20-32^{\circ} \mathrm{C}$ in L-15 medium supplemented with $5-20 \% \mathrm{FBS}$, the optimum growth was observed at $28^{\circ} \mathrm{C}$ with $20 \%$ FBS concentration. There is a little bit of elasticity with respect to growth when compared to human or other animal cell lines. Similar results were obtained in other fish cell lines viz. Retinal cell line from Danio rerio (Nambi et al., 2015), caudal fin cell line from Pangasianodon hypophthalmus (Soni et al., 2018), kidney cell line from Anguilla anguilla (Chen et al., 2019) etc. The SREM-1 cell line was sub-cultured for more than 55 times over a period of 10 months. Continuously maintaining cell lines is not feasible either from handling point nor is it a good practice from genetics point. Further, there can be chances of loss of culture due to contamination or other reasons. Hence, cryopreservation is essential and required for long term storage and to prevent genetic changes. SREM-1 cell line exhibited $70-80 \%$ viability on revival after cryopreservation period of 6 months in vapour phase of LN2. There were no noticeable changes in cell morphology during revival of cryopreserved cells. Similar observations have been reported by others. Rodriguez et al. (2014) reported $80 \%$ cell viability after storage in liquid storage in pronephros cell line of Salmo salar. Nambi et al. (2015) reported recovery of 75\%$80 \%$ of the $D$. rerio retinal cells after thawing after cryopreservation with no changes in growth or morphology.

Mitochondrial DNA genes, viz. COI and 16S rRNA, were amplified and sequenced from the SREM-1 cell line that confirmed the origin of the cell line to be $S$. richardsonii. In fish cell lines, the dominant cell types have been reported to be either fibroblast-like or epithelial-like cells (Lakra et al., 2011). In this study, SREM-1 cells were confirmed as epithelial-like by immuno-staining with epithelial marker, cytokeratin. It has been reported that the modal chromosome number
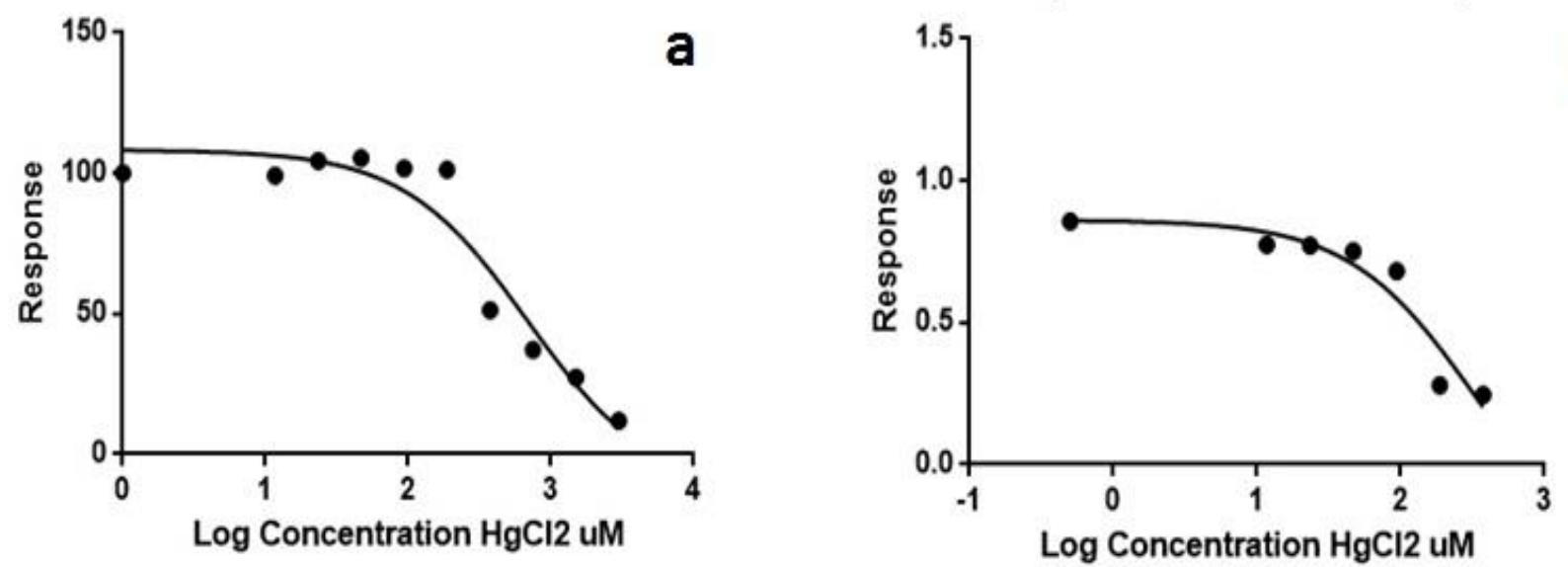

Figure 8. Dose response curve of $\mathrm{HgCl}_{2}$, assessed by: (a) alamarBlue, and (b) NR assays. 
for the species is 98 (Sharma et al., 1992; Lakara et al., 1997) and 96 (Vasave et al., 2016). In the present study, a majority of the SREM-1 cells revealed diploid chromosome number $(2 \mathrm{~N})$ as 98 . There was asymmetry of cells observed in some metaphase spreads. Similar observation was made by Goswami et al. (2013). High plating efficiency was observed at very cell densities only. The cell doubling time was estimated to be $34 \mathrm{~h}$. Marques et al. (2007) had reported it to be 36 to $48 \mathrm{~h}$ in Sparus aurata vertebral cell line. Dhararatnam et al. (2020) reported doubling time of $33.9 \mathrm{~h}$ in caudal fin cell line of Carassius auratus. The cell growth and doubling time is generally better in fish cell lines than human or other animal cell lines. Mycoplasma contamination has become a major issue in cell line research from the last decade as they can unnoticed and unrecognized for a long time but are deleterious to cells (Drexler et al., 2017; Corral-Vazquez et al., 2017). Screening for mycoplasma has become essential, especially if the intention is to distribute the cell line to other labs for research purposes. The SREM-1 cells were found free from mycoplasma.

In the present study, the SREM-1 cell line was also tested for its use in ctyotoxicity studies. To determine its suitability for cytotoxicity testing as a model, its response to a heavy metal, merucy chloride was studied. The alamarBlue and NR uptake assays are one of the most commonly used in vitro cytotoxicity tests. Mercury chloride is a toxic heavy metal element used in several industrial components, like batteries, pesticides, fireworks, laboratory chemicals, cosmetics, medical instruments etc., which can then find its way to the aquatic environment. It has also an inorganic form of ionic mercury that has widely been used in skin creams and other cosmetics. In the present study, SREM-1 cell line responded to the presence of $\mathrm{HgCl}_{2}$. After exposure of cells to higher $\mathrm{HgCl}_{2}$ concentrations, the cells started dying. With increasing concentration of the toxicant, there was a gradual decrease in absorption values in both alamarBlue and NR assays. The results are similar to those observed by researchers in other cell lines viz. primary haemocyte culture of Penaeus monodon (Jose et al., 2011) and neural cells of Chelonia mydas (Tong et al., 2016), indicating its potential to be used for cytotoxicity or eco-toxicological studies. The transfection efficiency of SREM-1 cells was also found good, indicating its potential for conducting transfection or genetic manipulation and gene expression studies. Barat et al. (2016) generated large scale next generation sequencing (NGS) data for thermal tolerance in this species. The SREM-1 cell line could be used for validating such results.

\section{Conclusion}

A new cell line, named SREM-1, was successfully developed from the eye muscle tissue of an important coldwater fish species of Himalayan waters, viz. S. richardsonii, that was found suitable for toxicological and gene expression studies. The cell line has been deposited in NRFC at ICAR-NBFGR, Lucknow, India, and any researcher who wish use the cell line for R\&D work could easily access from the NRFC on request.

\section{Acknowledgements}

The authors are thankful to the Director, ICARNBFR, Lucknow, and Director, ICAR-CIFA, Bhubaneswar, for support and providing the necessary facilities to carry out this work. The above work was carry out with the funds provided by the Department of Biotechnology (DBT), Ministry of Science and Technology, Government of India, New Delhi, vide the project Grant No. BT/PR13908/AAQ/3/733/2015. The authors duly acknowledge the support provided by DBT and are thankful for the same.

\section{References}

Ahmed, V.P., Chandra, V., Sudhakaran, R., Kumar, S.R., Sarathi, M., Babu, V.S., Bhonde R., \& Hameed, A.S.S. (2009). Development and characterization of cell lines derived from rohu, Labeo rohita (Hamilton) and catla, Catla catla (Hamilton). Journal of Fish Diseases, 32, 211-218. DOI: 10.1111/j.1365-2761.2008.00966.x

Babu, V.S., Chandra, V., Nambi, K.S.N., Majeed, A.S., Taju, G., Patole, M.S., \& Hameed, A.S.S. (2011). Development and characterization of novel cell lines from Etroplus suratensis and their applications in virology, toxicology and gene expression. Journal of Fish Biology, 80: 312334. https://doi.org/10.1111/j.1095-8649.2011.03167.x

Barat, A., Sahoo, P.K., Kumar, R., Goel, C., \& Singh, A.K. (2016). mRNA-Transcriptional response to heat shock in liver of snow trout (Schizothorax richardsonii)-a vulnerable Himalayan Cyprinid fish. Functional and Integrative Genomics, 16:1-11. https://doi.org/10.1007/s10142016-0477-0

Bols, N.C., Barlian, A., Chirinotrejo, M., Caldwell, S.J., Goegan, P., \& Lee, L.E. (1994). Development of a cell line from primary cultures of rainbow trout, Oncorhynchus mykiss (Walbaum), gills. Journal of Fish Diseases, 17:601-611. https://doi.org/10.1111/j.1365-2761.1994.tb00258.x

Castano, A., Bols, N., Braunbeck, T., Dierickx, P., Halder, M., Isomaa, B., Kawahara, K., Lee, L.E.J., Mothersill, C., Part, P., Repetto, G., Sintes, J.R., Rufli, H., Smith, R., Wood, C., Segner, H. (2003). The use of fish cells in ecotoxicologythe report and recommendations of ECVAM workshop 47. Alternatives to Lab Animals, 31: 317-351.

Chen, B., Zheng, Z., Yang, J., Chi, H., Huang, H., \& Gong. H. (2019). Development and characterization of a new cell line derived from European eel Anguilla anguilla kidney. Biology Open, 8. https://doi.org/10.1242/bio.037507

Corral-Vazquez, C., Aguilar-Quesada, R., Catalina, P., Aguilar, G.L., Ligero, G., Miranda, B., Carrillo-Avila, J.A. (2017). Cell lines authentication and mycoplasma detection as minimum quality control of cell lines in biobanking. Cell and Tissue Banking, 18, 271-280. https://doi.org/10.1007/s10561-017-9617-6

Dharmaratnam, A., Kumar, R., Valaparambil, B.S., Sood, N., Pradhan, P.K., Das, S., \& Swmaninatha, T.R. (2020). Establishment and characterization of fantail goldfish fin (FtGF) cell line from goldfish, Carassius auratus for in 
vitro propagation of Cyprinid herpes virus-2 (CyHV-2). PeerJ 8: e9373. https://doi.org/10.7717/peerj.9373

Drexler, H.G., Dirks, W.G., Macleod, R.A.F., \& Uphoff, C.C. (2017). False and mycoplasma-contaminated leukemialymphoma cell lines: time for a reappraisal. International Journal of Cancer, 140(5):1209-1214. https://doi.org/10.1002/ijc.30530

Driever, W., \& Rangini, Z. (1993). Characterization of a cell line derived from zebrafish embryos. In vitro Cellular and Developmental Biology-Animal, 29A (9): 749-754. https://doi.org/10.1007/BF02631432

Freshney, R.I. (1994). Culture of Animal Cells: A Manual of Basic Technique. Wiley-Liss, New York.

Freshney, R.I. (2005). Culture of Animal Cells - A Manual of Basic Techniques. Wiley-Liss, New York, NY, USA, pp. 641.

Goswami, M., Sharma, B.S., Bahuguna, S.N., Nagpure, N.S., \& Lakra, W.S. (2013). A SRCF Cell line from Schozothorax richarsonii: Development and Characterization, Tissue Cell: 219-256.

https://doi.org/10.1016/j.tice.2013.02.002

Goswami, M., Sharma, B.S., Tripathi, A.K., Yadav, K., Bahuguna, S.N., Nagpure, N.S., Lakra, W.S., \& Jena, J.K. (2012). Development and characterization of cell culture systems from Puntius (Tor) chelynoides (McClelland). Gene, 500(1):140-147.

https://doi.org/10.1016/j.gene.2012.03.016

Hightower, L.E., \& Renfro, J.L. (1988). Recent applications in fish cell culture to biomedical research. Journal of Experimental Zoology, 248: 290-302. https://doi.org/10.1002/jez.1402480307

Huang, Y.C., \& Han, Y.S. (2014). Determining antibetanodavirus compounds through a GF-1 cell-based screening platform. Antiviral Research, 105: 47-53. https://doi.org/10.1016/j.antiviral.2014.02.018

Jose, S., Jayesh, P., Mohandas, A., Philip, R., \& Singh, I.S.B. (2011). Application of primary haemocyte culture of Penaeus monodon in the assessment of cytotoxicity and genotoxicity of heavy metals and pesticides. Marine Environmental Research, 71: 169-177. https://doi.org/10.1016/j.marenvres.2010.12.008

Kapila, R., Kapila, S., \& Basade, Y. (2002). Impact of temperature variation on haematology and serum enzymes of Schizothorax richardsonii (Gray). Indian Journal of Fisheries, 49: 187-192.

Khan, M.A. (2004). Environmental Appraisal of depleting Fish diversity of Kashmir Valley. Chapter 23. Fishery Management. Ed. Arvind Kumar, A.P.H Publishing Corporation. New Delhi. pp. 175-179.

Lakra, W.S., Bhonde, R.R., Sivakumar, N., \& Ayyappan, S. (2006). A new fibroblast like cell line from the fry of golden mahseer Tor putitora (Ham). Aquaculture, 253:238-243.

https://doi.org/10.1016/j.aquaculture.2005.09.021

Lakra, W.S., John, G., \& Barat, A. (1997). Cytogenetic studies on endangered and threatened fishes.2. Karyotypes of two species of snow-trout, Schizothorax richardsonii (Gray) and S. kumaonensis (Menon). Proceedings of the National Academy of Sciences, India, Section B: Biological Sciences, 67(1): 79-81.

Lakra, W.S., Swaminathan, T.R., \& Joy, K.P. (2011). Development, characterization, conservation and storage of fish cell lines: A review. Fish Physiology and Biochemistry, 37(1): 1-20.

https://doi.org/10.1007/s10695-010-9411-x
Lannan, C.N., Winton, J.R., \& Fryer, J.L. (1984). Fish cell lines: establishment and characterization of nine cell lines from salmonids. In Vitro, 20: 671-676. https://doi.org/10.1007/BF02618871

Mallik, S.K., Shahi, N., Das, P., Pandey, N.N., Haldar, R.S., Kumar, A., \& Chandra, S. (2015). Occurrence of Ichthyophthirius multifiliis (White spot) infection in snow trout, Schizothorax richardsonii (Gray) and its treatment trial in control condition. Indian Journal of Animal Research 49 (2):227-30. http://dx.doi.org/10.5958/0976-0555.2015.00113.2

Marques, C.L., Rafael, M.S., Cancela, M.L., \& Laize, V. (2007). Establishment of primary cell cultures from fish calcified tissues, Cytotechnology, 55: 9-13. https://dx.doi.org/10.1007\%2Fs10616-007-9098-8

Nagpure, N.S., Mishra, A.K., Ninawe, A.S., Rasal, A., Dubey, A., Kumar, A., Goswami. M., Kumar, R., \& Jena, J.K. (2016). Molecular and cytogenetic characterization of fish cell lines and its application in aquatic research. National Academy Science Letters, 39(1): 11-16. https://doi.org/10.1007/s40009-015-0365-5

Nambi, K.S.N., Majeed, A.S., Taju, G., Sivasubbu, S., Raj, N.S., Madan, N., \& Hameed, A.S.S. (2015). Development and Use of Retinal Pigmented Epithelial Cell Line from Zebrafish (Danio rerio) for Evaluating the Toxicity of Ultraviolet-B. Zebrafish, 12(1): 21-32. https://doi.org/10.1089/zeb.2014.1012

Palumbi, S.R., Martin, A., Romano, S., McMillan, W.O., Stice, L., \& Grabowski, G. (1991). The simple fool's guide to PCR, Version 2.0. Privately published. Honolulu: Department of Zoology, University of Hawaii.

Rodriguez, S.J., Gonzalez, C., Monras, M., Romero, A., Ballesteros, N., Enriquez, R., \& Perez- Prieto, S. (2014). Establishment and characterization of a new cell line (SSP-9) derived from Atlantic salmon Salmo salar that expresses type lifn. Journal of Fish Biology, 85: 15261545. https://doi.org/10.1111/jfb.12503

Schirmer, K. (2006). Proposal to improve vertebrate cell cultures to establish them as substitutes for the regulatory testing of chemicals and effluents using fish. Toxicology, 224:163-183. https://doi.org/10.1016/j.tox.2006.04.042

Sharma, O.P., Gupta, S.C., Tripathi, N.K., \& Kumar, R. (1992.) On the chromosomes of two species of fishes from Jammu. Perspectives in cytology and genetics (eds. Manna GK, Roy SC). 7: 1211- 1215.

Singh, N., S, Murali., Kushwaha, B., Srivastava, J.K., Srivastava. S., Mishra, A.K., \& Kumar, R. (2019). In vitro culture and characterization of testis-derived cells from Clarias magur (Hamilton, 1822). Proceedings of the National Academy of Sciences, India, Section B: Biological Sciences, 89: 1017-1025. https://doi.org/10.1007/s40011-018-1020-y

Soni, P., Pradhan, P.K., Swaminathan, T.R., \& Sood, N. (2018). Development, characterization and application of a new epithelial cell line from caudal fin of Pangasianodon hypophthalmus (Sauvage 1878). Acta Tropica, 182: 215222. https://doi.org/10.1016/j.actatropica.2018.03.015

Tandel, R.S., Dash, P., Bhat, R.A.H., Sharma, P., Kalingapuram, K., Dubey, M., \& Sarma, D. (2020). Molecular Characterization of Saprolegnia Spp. From Himalayan Snow Trout, Schizothorax richardsonii: A Case Study Report. Aquaculture, 531,735824. https://doi.org/10.1016/j.aquaculture.2020.735824 
Tong, J., Wang, Y., \& Lu, Y. (2016). In vitro evaluation of inorganic and methyl mercury mediated cytotoxic effect on neural cells derived from different animal species. Journal of Environmental Science, 41:138-145. https://doi.org/10.1016/j.jes.2015.04.036

Vasave, S., Saxena, A., \& Srivastava, S. (2016). Karyotypic diversity between rainbow trout (Oncorhynchus mykiss, Walbaum) and snow trout (Schizothorax richardsonii, Gray). Journal of Plant and Agriculture Research, 2(1):15.

Villena, A.J. (2003). Applications and needs of fish and shellfish cell culture for disease control in aquaculture. Reviews in Fish Biology and Fisheries, 13: 111-140.
Vishwanath, W. (2010) Schizothorax richardsonii. In: IUCN 2011. IUCN Red List of Threatened Species. Version 2011.2

Ward, R.D., Zemlak, T.S., Innes, B.H., Last, P.R., \& Hebert, P.D. (2005). DNA barcoding Australia's fish species. Philosophical Transactions of the Royal Society B: Biological Sciences, 360:1847-1857. https://doi.org/10.1098/rstb.2005.1716

Wolf, K., \& Quimby, M.C. (1962). Established eurythermic line of fish cells in vitro. Science, 135: 1065-1066. https://doi.org/10.1126/science.135.3508.1065 